\title{
STRATEGY IN DEVELOPING CLOVE FARMING AT NORTH TINANGKUNG DISTRICT OF BANGGAI ISLAND
}

\author{
Mohamad Wahyudi' ${ }^{1)}$, Saiful Darman'), Made Antara ${ }^{3)}$ \\ ${ }^{1)}$ Regional Planning Agency and Research Development Banggai District. Central Sulawesi Province \\ e-mail: yudhiotaya@gmail.com \\ ${ }^{2)}$ Lecturer and Researcher at Department of Agrotechnology Faculty of Agriculture University of Tadulako, Palu \\ ${ }^{3)}$ Lecturer and Researcher at Department of Agribusiness Faculty of Agriculture University of Tadulako, Palu
}

\begin{abstract}
This research is aimed at determining strategy for developing Clove Farming in Banggai Kepulauan district. The research site is chosen purposively based on the consideration that the site has become one of the districts favored for clove farming development in Banggai Kepulauan district. The sample was taken by employing simple random sampling methode $15 \%$ from the village population.Total number of respondents was 24 . The data analysis employed in this research was SWOT. Results of SWOT analysis indicated that clove farming belonged to III quadran (supporting turn around strategy) with WO strategy (weakness-opportunities). Programme or activity proposed, includes: (1) Application of business oriented management with the use of technology development, (2) Linkages with partners/cooperation with financial institution for capital assisstance, and (3) Cooperation with academics/government institution for human resource development.
\end{abstract}

Key Words : Clove, strategy, SWOT.

\section{INTRODUCTION}

The targets of development that needs to be achieved is a balanced economic structure, where ability and strength of the industrial sector is supported by the strength of agriculture that can increase the optimal utilization of natural resources, labor, capital, and technology existing in the physical and social environment as well as improvement of farmers' welfare (Ruhnayat, 2001). One of the efforts undertaken to support this purpose is to increase the utilization of diverse agricultural commodities, including cloves (Gusnawati, et al., 2014).

Clove is one of the agricultural commodities with high economic value. For Indonesia, cloves have economic value which is very important and strategic because these commodities can be used as a mixture for making cigarette that generates great revenue from its tax. Besides its use as additional substance for cigarettes, clove is also useful as a spice required in the field of medicine and it can also be used as materials for making volatile oil (Arisen, K.M., 2009)
In average the production of clove plantation crop in 2014 was 3,832 tonnes, with a total area of 257.88 ha and productivity of 0.14 tonnes / ha. This shows that the production of clove plantation was relatively given the size of the plantation.

One factor causing the clove to be widely cultivated by society is its high economic value. In addition to improving the economic of those working in the cloves farming, it can also provide employment for the society (Wandi, et al., 2016).

Based on the description above, it is important to conduct a reserch with the purpose of determining strategies for developing clove farming in the district of North Tinangkung Banggai Islands.

\section{RESEARCH METHODS}

Research site was chosen purposively by considering that North Tinangkung subdistrict is one of the favourite subdistricts in developing clove production in the district of Banggai Island. 
Population in this research is 157 heads of family who work as clove farmers consisting of four villages (Palam village, Tatakalai village, Ponding-ponding village and Lalong village). The sample of this study was taken by using applying simple random sampling method) with $15 \%$ from population per village Gay in Hasan (2002). Therefore the number of sample in each can be illustrated in Table 1 .

\section{Data Analysis}

SWOT Analysis. To determine the strategies in developing clove farming at North Tinangkung subdistrict, district of Banggai Islands, SWOT analysis was conducted. This analysis was done to identify systematic factors for formulating a strategy based on a logic that maximises Strenght and Opportunity, but at the same time minimizes Weakness and Threat.

\section{RESULT AND DISCUSSION}

SWOT Analysis. The use of SWOT analysis in this research is intended to find out strength and weakness in the internal factors (IFAS) with opportunity and threat that belong to external factors (EFAS) in clove farming at North Tinangkung subdistrict, district of Banggai Islands.

Identification of Internal Strategy Factor (IFAS). Based on the results of questionnaires and focus group discussion (FGD) at the study site, it was found that there were five strengths of internal enviroment factors and weakness influencing the purpose of developing clove farming at North Tinangkung subdistrict, then the evaluation was conducted and presented in Table 3.

Tabel 1. Number of Popultion and Sample at North Tinangkung Subdistrict

\begin{tabular}{clcc}
\hline No & \multicolumn{1}{c}{ Desa } & $\begin{array}{c}\text { Populasi } \\
(\mathrm{KK})\end{array}$ & $\begin{array}{c}\text { Sampel } \\
(\mathrm{KK})\end{array}$ \\
\hline 1 & Palam & 3 & 1 \\
2 & Tatakalai & 45 & 7 \\
3 & Ponding-ponding & 82 & 12 \\
4 & Lalong & 27 & 4 \\
\hline & \multicolumn{1}{c}{ Jumlah } & 157 & 24 \\
\hline
\end{tabular}

Source: Primary Data Analysis Result, 2016.

Table 2. Scope of Internal Strategy Factor Evaluation

\begin{tabular}{ll}
\hline No & \multicolumn{1}{c}{ Internal Factor } \\
\hline 1. & Strengths \\
& a. Existing farmers' group \\
& b. Farmers high motivation \\
& c. Farmers' experience \\
& d. Quality of product \\
& e. $\quad$ Uniqueness of product
\end{tabular}

2. Weakness
a. Farming management
b. Possession of narrow land
c. Inadequate capital
d. Low level of education
e. Location of Farm

Source: Primary Data Analysis, 2016.

Table 3. Matrix of SWOT Analysis (IFAS) in Developing Clove Farming at North Tinangkung Subdistrict.

\begin{tabular}{|c|c|c|c|c|c|}
\hline No & Internal Environment & $\begin{array}{l}\text { Weight } \\
\text { (a) }\end{array}$ & $\begin{array}{l}\text { Rating } \\
\text { (b) }\end{array}$ & $\begin{array}{l}\text { Score } \\
(\mathrm{axb})\end{array}$ & $\begin{array}{c}\text { Explanation } \\
(\%)\end{array}$ \\
\hline $\mathrm{A}$ & Strengths & & & & \\
\hline 1 & Existing Farmers' Group & 0,13 & 4 & 0,53 & \\
\hline 2 & Farmers High Motivation & 0,11 & 3 & 0,32 & \\
\hline 3 & Farmers' Experience & 0,11 & 3 & 0,32 & \\
\hline 4 & Quality of Product & 0,08 & 2 & 0,16 & \\
\hline \multirow[t]{2}{*}{5} & Uniqueness of Product & 0,08 & 2 & 0,16 & \\
\hline & Jumlah A & 0,50 & 14 & 1,47 & 48,28 \\
\hline B & Weaknesses & & & & \\
\hline 1 & Farming Management & 0,05 & 1 & 0,05 & \\
\hline 2 & Possession of Narrow Land & 0,08 & 2 & 0,16 & \\
\hline 3 & Limitation of Capital & 0,11 & 3 & 0,32 & \\
\hline 4 & Low Level of Education & 0,13 & 4 & 0,53 & \\
\hline \multirow[t]{3}{*}{5} & Location of Farm & 0,13 & 4 & 0,53 & \\
\hline & Jumlah B & 0,50 & 14 & 1,58 & 51,72 \\
\hline & Total A + B & 1,00 & 28 & 3,05 & 100,00 \\
\hline
\end{tabular}

Source: Primary Data, 2016. 
The results of internal factor analysis indicated the strength percentage of cloves farming development is $48.28 \%$ and weaknesses of $51.72 \%$. It shows that the farm has a greater weakness than its strength.

internal strategy factor evaluation

Result of external factor analysis showed that opportunity for developing clove farming is 60,34. Result of external factor analysis showed that the opportunity percentage for developing clove farming is $60,34 \%$ and the threath is $39,66 \%$. This indicates that the percentage of opportunity is greater than its threat.

\section{Identification of External Factor Strategy (EFAS)}

Table 4. Scope of Internal Strategy Factor Evaluation

\begin{tabular}{ll}
\hline No & \multicolumn{1}{c}{ Internal Factor } \\
\hline 1. & Strengths \\
& a. Simple marketing \\
b. Distribution Channels and good & system of information \\
c. Partnership & \\
d. Local Government Support \\
e. & Advanced Technology \\
\hline
\end{tabular}

2. Weakness
a. Uncertainty in climate
b. Labor
c. OPT attacks
d. Price determined by buyer
e. Competitor

Table 5. Analysis of SWOT Matrix (EFAS) in Developing Clove Farming at North Tinangkung Subdistrict

\begin{tabular}{clcccc}
\hline No & \multicolumn{1}{c}{ External Enviroment } & weight(a) & $\begin{array}{c}\text { Rating } \\
(\mathrm{b})\end{array}$ & $\begin{array}{c}\text { Score } \\
(\mathrm{axb})\end{array}$ & $\begin{array}{c}\text { Explanation } \\
(\%)\end{array}$ \\
\hline A & Opportunities & & & & \\
1 & Simple marketing & 0,13 & 4 & 0,53 & \\
2 & Distribution Channel and Good Information & 0,13 & 4 & 0,53 & \\
& System & 0,11 & 3 & 0,32 & \\
4 & Partnership & 0,11 & 3 & 0,32 & \\
5 & Local Government Support & 0,08 & 2 & 0,16 & \\
\hline$\quad$ Advanced Technology & 0,55 & 16 & 1,84 & 60,34 \\
\hline Jumlah A & & & & \\
1 & Ancaman (Threats) & 0,05 & 1 & 0,05 & \\
2 & Uncertainty of Climate & 0,08 & 2 & 0,16 & \\
3 & Oabor Attacks & 0,08 & 2 & 0,16 & \\
4 & Price Determined by Buyer & 0,11 & 3 & 0,32 & \\
5 & Competitor $\quad 0,13$ & 4 & 0,53 & \\
\hline$\quad \quad$ Jumlah B & 0,45 & 12 & 1,21 & 39,66 \\
\hline$\quad$ Jumlah A + B & 1,00 & 28 & 3,05 & 100,00 \\
\hline
\end{tabular}

Source: Primary Data after analysis, 2016.

Table 6 . Matrix of IFAS and EFAS Strategies for developing Clove Farming at North Tinangkung Subdstrict.

\begin{tabular}{lcc}
\hline EFAS & Strenghts (S) & Weaknesses (W) \\
\hline \multirow{2}{*}{ Opportunities (O) } & Strategy (SO) & Strategy (WO) \\
& $1,47+1,84=3,32$ & $1,58+1,84=3,42$ \\
Treats $(\mathrm{T})$ & Strategy $(\mathrm{ST})$ & Strategy (WT) \\
& $1,47+1,21=2,68$ & $1,58+1,21=2,79$ \\
\hline
\end{tabular}

Source: Primary Data after Analysis, 2016. 
Table 7. SWOT Matrix of Clove Farming Development

\begin{tabular}{|c|c|c|}
\hline External Factor & $\begin{array}{l}\text { Strengths }(\mathrm{S}) \\
\mathrm{S}_{1} \text {. Existing Farmers' group } \\
\mathrm{S}_{2} \text {. Farmers' high motivation } \\
\mathrm{S}_{3} \text {. Farmers experience } \\
\mathrm{S}_{4} \text {. Quality of product } \\
\mathrm{S}_{5} \text {. Uniqueness of product }\end{array}$ & $\begin{array}{l}\text { Weaknesses/ Weakness }(\mathrm{W}) \\
\mathrm{W}_{1} \text {. Farming management } \\
\mathrm{W}_{2} \text {. Ownership of narrow land } \\
\mathrm{W}_{3} \text {. Limitation of capital } \\
\mathrm{W}_{4} \text {. Farmers' low level of education } \\
\mathrm{W}_{5} \text {. Farm location }\end{array}$ \\
\hline Opportunities $(\mathrm{O})$ & Strategy $(\mathrm{SO})$ & Strategy \\
\hline $\mathrm{O}_{1}$. Simple Marketing & $\begin{array}{l}\text { 1. Increasing production of } \\
\text { clove because of its unique }\end{array}$ & $\begin{array}{l}\text { 1. Applying management of farm that } \\
\text { is oriented to bussiness with the use }\end{array}$ \\
\hline $\begin{array}{l}\mathrm{O}_{2} \cdot \begin{array}{l}\text { Distribution channel and } \\
\text { good information system }\end{array}\end{array}$ & $\begin{array}{l}\text { products involving existing } \\
\text { farmers' group. }\left(\mathrm{S}_{1}, \mathrm{O}_{1}\right)\end{array}$ & $\begin{array}{l}\text { of latest technology. }\left(\mathrm{W}_{1}, \mathrm{O}_{5}\right) \\
\text { 2. Partnership with financial institution }\end{array}$ \\
\hline $\mathrm{O}_{3} . \quad$ Partnership & $\begin{array}{l}\text { 2. Increasing quality of products } \\
\text { with the use of the latest } \\
\text { technology }\left(\mathrm{S}_{4}, \mathrm{O}_{5}\right)\end{array}$ & $\begin{array}{l}\text { to obtain financial support. }\left(\mathrm{W}_{3}, \mathrm{O}_{3}\right) \\
\text { 3. Cooperating with academic } \\
\text { staff/government institution to }\end{array}$ \\
\hline $\begin{array}{l}\mathrm{O}_{4} \text {. Local government } \\
\text { support }\end{array}$ & $\begin{array}{l}\text { 3. Developing distribution } \\
\text { channel and information to } \\
\text { simplify the marketing }\end{array}$ & develop human resources. $\left(\mathrm{W}_{4}, \mathrm{O}_{4},\right)$ \\
\hline $\mathrm{O}_{5}$. Advanced technology & system. $\left(\mathrm{S}_{4}, \mathrm{O}_{2}\right)$ & \\
\hline Ancaman/Thre & Strate & Strate \\
\hline $\mathrm{T}_{1}$.Uncertainty of climate & $\begin{array}{l}\text { 1. Optimizing f } \\
\text { experience to }\end{array}$ & $\begin{array}{l}\text { 1. Optimizing existing capital to pay } \\
\text { labors. }\left(\mathrm{W}_{3}, \mathrm{~T}_{2}\right)\end{array}$ \\
\hline $\mathrm{T}_{2}$. Labors & $\begin{array}{l}\text { OPT attacks. }\left(\mathrm{S}_{3}, \mathrm{~T}_{3}\right) \\
\text { 2. } \\
\text { Attempting to increase }\end{array}$ & $\begin{array}{l}\text { 2. Increasing farmers' knowledge in } \\
\text { anticipating uncertain climate. }\end{array}$ \\
\hline $\mathrm{T}_{3}$. OPT attacks & $\begin{array}{l}\text { quality of products to retain } \\
\text { existing prices. }\left(\mathrm{S}_{4}, \mathrm{~T}_{4}\right)\end{array}$ & $\begin{array}{l}\left(\mathrm{W}_{4}, \mathrm{~T}_{1}\right) \\
\text { 3. Innovations in the field to }\end{array}$ \\
\hline $\begin{array}{l}\mathrm{T}_{4} . \\
\begin{array}{l}\text { Price determined by } \\
\text { buyers }\end{array}\end{array}$ & $\begin{array}{l}\text { 3. Keeping distribution } \\
\text { channel and information to } \\
\text { anticipate competitor from }\end{array}$ & $\begin{array}{l}\text { anticipate uncertainty in prices. } \\
\left(\mathrm{W}_{2}, \mathrm{~T}_{4}\right)\end{array}$ \\
\hline $\mathrm{T}_{5}$. Competitor & outsid & \\
\hline
\end{tabular}

Source: Primary Data after Analysis, 2016.

Alternative Strategy Development of Clove Farming. Technique to obtain formulation of alternative strategy and activity conducted in developing clove farming production at North Tinangkung subdistrict is presented in SWOT matrix in Table 7.

W-O (Weaknessess-Opportunities) Strategy. W-O Strategy is a strategy that incorporates opportunities of external factor with weaknessess of internal factor in clove farming at North Tinangkung subdistrict. The purpose of this strategy is to minimize internal weaknessess by taking advantage of available opportunity. The most feasible alternatives of strategy that can taken into account are as follows:

a. Applying management of farming that is oriented in bussiness by making use of advanced technology. b. Partenership with financial institution for financial support.

c. Organizing training by involving academic staff/government institution for human resources development.

Recomended Strategy. W-O model strategy belongs to III quadran in the analysis of SWOT diagram that incorporates opportunities of external factors with weaknessess of internal factors that become main strategy in clove farming.

Optimizing strategies taken from the SWOT analysis, therefore recommended activities must be applied for developing clove farming production. In order that the reccomendation received appreciation and response from society, Focus Group discussion can be conducted through brainstorming method to explore ideas from participants. In this format, stakeholders 
who have capacity and competence to provide ideas must be involved. Referring to the results of SWOT analysis, there are 3 (three) alternative strategies need to be implemented:

\section{Applying Bussiness Oriented Management of Farming by Utilizing The Advanced Technology}

a. Through farmers' group, it is expected that they can cooperate with local government to increase knowledge of clove farmers through local government agency at the district of Banggai Islands.

b. Local government is expected to help clove farmes in North Tinangkung through socialization to change mindsets of the farmers especially those that deal with optimizing clove planting and ways to develop clove production by considering some techniques - technique of harvesting, cultivation and storage.

c. Local government can help farmers through agriculture department with provision of agricultural equipments such as dryer and harvest equipment.

d. Government through district-owned corporation (BUMD) msut help clove farmers in marketing.

\section{Partnership/Cooperation with Financial Institution for Financial Support.}

a. It is hoped that local government assists clove farmers by acting as a bridge between clove producers in this case farmers with those working in clove industry, and investors in order that they can work together to make use of opportunity in exporting clove products.

b. The banks can help providing financial support with low interest and without guarantee and to simplify process getting a loan service by clove farmers for developing their production.

To Cooperate with Academic Staff/ Government Institution for Developing Human Resources. In developing farming cloves, farmers should be assisted by the academia/university in searching for innovations and the latest breakthroughs, so that they can produce a higher quality and more varied products, not just selling the raw product in the form of dried flowers meliankan semi-finished products that can be utilized for product mix medicine, cooking and cosmetics. Universities are also expected to provide education and training on a regular basis to the clove farmers to adapt to current technological developments.

a. In develping clove farming, acadmics/ universities must be involved to create innovations and breakthrough to produce high quality products with more variations, not just selling raw products in the form of dried flowers but semifinished products that can be utilized for mix medicine products, cooking and cosmetics. Universities are also expected to provide education and training in a regular basis to the clove farmers to adapt to current technological developments.

b. Clove farmers through farmers' groups should approach and cooperate with universities around the district of Banggai Kepulauan for standardization of product quality testing clove in the laboratory to determine the composition and durability of the product. As practiced by large corporations, they do not hesitate to cooperate with research institutions to test the product in order to ensure its best quality. Some manufacturers even include research institutions to guarantee their products in its higher quality.

c. Through training conducted by local government areas and universities, clove farmers should be able to take the opportunity to further improve managerial capabilities, especially in the field of human resource management, planning, financial management, and market research in order to identify and monitor the development of product marketing, pricing and level of competition. Technological developments are also good to be followed and studied by clove farmers so that they can find out marketing opportunities of cloves. 
Tabel 8. Implementing Clove Faming Strategy at North Tinangkung Subdistrict

\begin{tabular}{|c|c|c|c|}
\hline No & Strategy (W-O) & Activities & Responsible Activities \\
\hline 1. & $\begin{array}{l}\text { Applying bussiness } \\
\text { oriented farm } \\
\text { management with the } \\
\text { use of the latest } \\
\text { technology }\left(\mathrm{W}_{1}, \mathrm{O}_{5}\right)\end{array}$ & $\begin{array}{l}\text { a. Increasing knowledge of clove } \\
\text { farmers through councelling } \\
\text { b. Changing mindsets of farmers } \\
\text { by optimizing clove planting } \\
\text { and increasing quality of clove } \\
\text { production } \\
\text { c. Obtaining farm equipment } \\
\text { such as picking tools and drier } \\
\text { d. Assissting process of clove } \\
\text { marketing. }\end{array}$ & $\begin{array}{l}\text { - Department of } \\
\text { Information } \\
\text { - Farmers Group } \\
\text { - Local Government } \\
\text { - Agriculture } \\
\text { Development } \\
\text { - Local Government } \\
\text { - Agriculture } \\
\text { Development } \\
\text { - Local Department } \\
\text { - BUMD }\end{array}$ \\
\hline 2. & $\begin{array}{l}\text { Partnership and } \\
\text { cooperation with } \\
\text { Financial institution for } \\
\text { financial support } \\
\left(\mathrm{W}_{3}, \mathrm{O}_{3}\right)\end{array}$ & $\begin{array}{l}\text { b. Providing financial capital for } \\
\text { clove farmers to develop their } \\
\text { bussiness }\end{array}$ & $\begin{array}{l}\text { - Government, } \\
\text { - Private, and } \\
\text { - Farmers/Famer's } \\
\text { family } \\
\text { - Banking and } \\
\text { - Private }\end{array}$ \\
\hline 3. & $\begin{array}{l}\text { Cooperating with } \\
\text { academics /local } \\
\text { government to develop } \\
\text { human resources } \\
\left(\mathrm{W}_{4}, \mathrm{O}_{4}\right)\end{array}$ & $\begin{array}{l}\text { b. Examining standards of } \\
\text { production quality at } \\
\text { Laboratory available in } \\
\text { University } \\
\text { c. Participating training conducted } \\
\text { by local government and } \\
\text { univeristy to develop } \\
\text { managerial ability especially } \\
\text { human resources, financial } \\
\text { management planning, and } \\
\text { marketting }\end{array}$ & $\begin{array}{l}\text { - University } \\
\text { - Information } \\
\text { Department } \\
\text { - Agriculture } \\
\text { Department } \\
\text { - Universities } \\
\text { - Research and } \\
\text { development Banggai } \\
\text { Island District }\end{array}$ \\
\hline
\end{tabular}

Source: Primary Data After Analysis, 2016.

\section{CONCLUSION AND SUGGESTION}

\section{Conclusion}

Based on the research development of cloves farming in North Tinangkung District, it can be concluded that the development of clove farming in the area belongs to III quadrant (supports strategic turn around) with WO strategy (weaknessessOpportunities); the company's strategy to take advantage of opportunities in order to overcome weaknesses, the program / activity as follows: (a) Implementing of businessoriented management with the use of technology, (b) Partnership/co-operation with financial institution for capital assistance and (c) Cooperating with academics/ government agencies for improving human resources.

\section{Suggestion}

Based on the results of this study, it is recommended: 
1. Considering the clove farming in the District of North Tinangkung is in quadrant III; the company's strategy to get benefit from the opportunities to overcome weaknesses, therefore, should work closely with industry / stakeholders to obtain the clove market, it is expected, the regional governments, Private parties, and Banking, helped bridge the clove farmers with industry / investor, to provide capital assistance for farmers clove in order to develop the business into a better direction.
2. To cooperate with academics/ government research institution to develop clove farming with activities such as: Seeking for new innovations and breakthrough to produce high quality products and many different varieties, both in conducting standard testing of products quality at Laboratory in Universities, and taking part in training conducted by local government and universities to develop managerial ability in human resources development; financial management planning, and research marketing.

\section{REFERENCES}

Arisena., K.M., 2009. Struktur dan Perilaku Pasar Komoditas Cengkeh di Kecamatan Busungbiu Kabupaten Buleleng. Ganec Swara Vol 3 (2) : 39-46.

Dinas Kehutanan Perkebunan Pertanian dan Peternakan, 2014. Laporan Angka Tetap (ATAP) Statistik Perkebunan 2011-2014. Dinas Kehutanan, Perkebunan, Pertanian dan Peternakan.

Gusnawati, Alimudin laapo dan Dafina Howara, 2014. Analisis Kelayakan Finansial Usahatani Cengkeh di Desa Bou Kecamatan Sojol Kabupaten Donggala Provinsi Sulawesi Tengah. e-journal Agrotekbis Vol 2 (3) : 325-331.

Hasan, M.I., 2002. Metodologi Penelitian dan Aplikasinya. Penerbit Ghalia Indonesia, Jakarta.

Rangkuti, F., 2006. Analisis SWOT Tehnik Membedah Kasus. Gramedia, Jakarta.

Wandi.B.L., Gene.H.M.K dan Juliana.R.M., 2016. Pola Pengalokasian Pendapatan Petani Cengkeh di Desa Kiawa I Kecamatan Kawangkoan Utara. Agri-Sosio Ekonomi Unsrat Vol 12 (2A) : 261-272. 